\title{
11. Imagining Flanders: The (De)construction of a Regional Identity in Fifteenth-Century Flanders
}

\author{
Lisa Demets
}

\begin{abstract}
This chapter examines the construction of collective historical identities in late medieval Flemish towns in the early fifteenth century. The Burgundian dukes and the Flemish elites tried to shape and 'control' representations of their principality, but in literary, pictorial, and historiographical sources the focus on the Flemish count gradually gave way to a focus on the largest Flemish cities. Analysing the Imago Flandriae, a Latin prophecy on the Hundred Years' War, and the Flandria Generosa C, a Latin chronicle of Flanders, I argue that these literary sources illustrate the new influence of major Flemish towns in new regional institutions, such as the Four Members of Flanders, and on regional politics under Burgundian rule.
\end{abstract}

Keywords: chronicles; Flanders; cities; ideology; elites

\section{Introduction}

Medievalists have been occupied with the cultural and social aspects of 'national', or, better, 'regional' identity for decades. ${ }^{1}$ Some scholars argued that already as early as the twelfth century, around 1111, something like

1 Guenée, Histoire et culture historique; Werner, 'Les nations et le sentiment national'. There are numerous publications on 'national identities' in the Low Countries, in particular for the county of Flanders and the duchy of Brabant: De Ridder, 'Dynastiek en nationaal gevoel'; Verbruggen, 'Het nationaal gevoel'; Stein, 'Nationale identiteiten'. In a volume on national identities combining research on identities in Flanders, Brabant, Friesland and Guelders, Robert Stein and Judith Pollmann argued how the concept of 'nationalism' can (carefully) be applied to some medieval principalities. Stein, 'Introduction', p. 5. However, following Walter Prevenier,

Damen, M. and K. Overlaet (eds.), Constructing and Representing Territory in Late Medieval and Early Modern Europe. Amsterdam: Amsterdam University Press, 2022 DOI 10.5117/9789463726139_CH11 
a 'Flemish identity' emerged in a poem by Petrus Pictor, a canon of the Church of Our Lady at Saint-Omer and a contemporary of the more famous writers Lambert of Saint-Omer, his colleague, and the comital secretary Galbert of Bruges. ${ }^{2}$ Indeed, in his De Laude Flandriae, Pictor pledged his love for the county of Flanders. Rather than a song of praise for the territory and land of Flanders, the poem was first and foremost a homage to the glory of the Flemish counts. ${ }^{3}$ Although Pictor frequently used the word terra to refer to the county, his eulogy focused exclusively on the comital dynasty, and not on Flemish towns, villages, borders, or landmarks. A just interpretation of this alleged early expression of 'Flemish identity' requires an analysis of the specific context in which De Laude Flandriae was written. Remarkably enough, the canon had been banished from his beloved county when he wrote his piece. Petrus Pictor was clearly more aware of his 'Flemish identity' while forced to be living abroad. It seems that expressions of 'regional identities' became particularly relevant when a person left his home region - an important consideration scholars should keep in mind when studying medieval representations of territorial and feudal affiliations. As Robert Stein has stated: 'It is especially in confrontations with strangers that we are forced to define ourselves. ${ }^{4}$ For instance, in trading networks within the county of Flanders, between the largest Flemish cities, such as Ghent, Bruges, and Ypres, merchants would be addressed by their specific individual hometown. In contrast, while trading abroad, they are referred to universally as 'Flemings'. 5 Examples of a 'Flemish identity' used within the context of the county are rather scarce until the late medieval period.

Although there are various possible ways to approach or define 'identity', I will refer to both individual and collective identities in this contribution as 'plural', 'composite', or 'multilayered' identities, shaped by several political, social, and cultural factors, but, more importantly, unstable and fluctuating over time. Issues of identity, belonging, and integration are recurrent in contemporary political discourses today. Belonging to a 'nation' nowadays does not merely begin or end with obtaining an official juridical status (citizenship) or with a financial obligation (paying taxes). Discourses of shared 'standards', 'behaviour', 'culture', and, of course, 'language' are

Wim Blockmans and Marc Boone, I prefer to use the more neutral concept of 'regional identities' for fifteenth-century Flanders, see Blockmans, 'Regionale Identität'.

2 Verbruggen, 'Het nationaal gevoel', p. 3; Van Acker, 'Petrus Pictor'.

3 Petrus Pictor, De Laude Flandriae, p. 132: 'Flandria diva, paris reges magnos comitesque'

('Divine Flanders, you gave birth to great kings and counts').

4 Stein, 'Introduction', p. 6.

5 Pajic, 'Flemish Rebels'. 
omnipresent in identity politics today. ${ }^{6}$ The layered meanings of such concepts are still subject of debate, in particular when applied to earlier historical periods. First and foremost, it is not clear if the term 'identity', which refers primarily to an individual attitude, can easily be applied to a group. The question of whether there are 'shared' or 'collective' identities is central not only to sociological or historical research, but also to social and political movements, both in the present and in the past. In this contribution, I will address how regional identities are related to territorial spaces in the late medieval county of Flanders. Doing so, I will focus on the construction of Flemish identities in the late medieval Flemish towns under the rule of the Burgundian dukes. Territory is a geographical concept which contains a political denotation. In contrast to Elden, I will approach the representation of a territory, in this case a principality, from a bottom-up perspective. ${ }^{7}$ First, not only the prince and his court are trying to shape and 'control' terrains and lands, but citizens, and, in particular, local or urban elites, as well. ${ }^{8}$ Second, ideological representations of territories were equally important to take into account apart from 'political technologies' such as measurements and borders. ${ }^{9}$ How did city dwellers in the county of Flanders identify with Flanders as a principality in the Late Middle Ages? I will illustrate how the focus on the prince, still central in the poem of Petrus Pictor, gradually shifted to a greater prominence of the largest Flemish cities in various representations of the county. Scrutinising this development, I will turn to literary, pictorial, and historiographical sources (such as a fifteenth-century prophecy and a Flemish chronicle) to offer a holistic approach to the cultural, social, and political factors influencing these changing representational strategies.

\section{Belonging to a region: The case of Flanders under Burgundian rule (1384-1482)}

For many years, regional identity was at the centre of the historical research on Burgundian 'state formation' and its processes of 'centralisation'. The question of whether there emerged a supra- or interregional identity between the

6 Anthias, 'Identity and Belonging'; Anthias, 'Where Do I Belong?'

7 I follow Stuart Elden's call for a more 'historical' and fluid approach to the concept of 'territory'. Elden, 'Land, Terrain, Territory', p. 810.

8 See the contribution of Jim van der Meulen in this volume for another bottom-up approach focusing on local lordships in the duchy of Guelders.

9 Elden, 'Land, Terrain, Territory', p. 811. 
different principalities of the Low Countries in the fifteenth and sixteenth centuries has been addressed by scholars such as Robert Stein and Judith Pollman. ${ }^{10}$ Following Wim Blockmans, Robert Stein among others saw a shared supra-regional identity in the Low Countries in the late fifteenth century, resulting in the request for a common 'Great Privilege' from Mary of Burgundy in 1477. Nevertheless, Elodie Lecuppre-Desjardin highlighted the regional aspects and discourses in the Great Privilege of Mary of Burgundy, and the necessity for other regional charters and urban privileges. ${ }^{11}$ Amongst other towns in the Low Countries, Ghent and Bruges were both granted individual urban privileges. ${ }^{12}$

Surprisingly, Stein, Blockmans, and Lecuppre-Desjardin took the regional identity of each principality as a self-evident point of departure for their research. In fact, regional identity was not at all 'obvious' nor 'completed' at the beginning of the Burgundian dukes' rule over the different principalities in the Low Countries. By combining top-down and bottom-up approaches, Marc Boone argued that most principalities in the Low Countries developed a sort of 'regional identity' through the princely dynasty, central institutions, and fiscal policy of the Burgundian dukes. ${ }^{13}$ The Burgundian dukes were heavily influenced by the French royal ideology of absolute sovereign power, which then found expression in central institutions such as regional and supra-regional courts of justice and regional chambers of accounts. Furthermore, the state-making process of the Burgundian dukes was also a cultural one, as exemplified by the cultural splendours of the Burgundian court. ${ }^{14}$ In this regard, Boone pointed to 'the Burgundian appropriation of the collective memory of the principalities of the Low Countries' through a deliberate policy of gradually integrating historiographical traditions. ${ }^{15}$ This is true, at least, for the duchy of Brabant and the county of Hainaut, where historiographical projects were initiated by Philip the Good around 1440. ${ }^{16}$ There are very few examples of Flemish chronicles related directly to the Burgundian dynasty, let alone evidence that any were commissioned

\footnotetext{
10 Stein, 'Introduction'.

11 Lecuppre-Desjardin, Le royaume inachevé, p. 280.

12 Haemers, For the Common Good, pp. 166, 231.

13 Boone, 'Flemish and Brabantine Identity'.

14 Brown, 'Bruges and the Burgundian "Theatre-State"'; Van Bruaene, 'The Habsburg Theatre State'. The cultural splendour of the Burgundian dukes was, of course, central in the work of Johan Huizinga: Huizinga and Van der Lem, Herfsttij der Middeleeuwen.

15 Boone, 'Flemish and Brabantine Identity'.

16 Stein, Politiek en historiografie; Lecuppre-Desjardin, La ville des cérémonies; Small, 'Les Chroniques de Hainaut'.
} 
by the dukes themselves. However, as Robert Stein and Graeme Small illustrated, this historiographical campaign in Brabant and Hainaut was heavily embedded, if not initiated, by local urban and noble elites. ${ }^{17}$

Examples for the nearby duchy of Brabant are more common. Moreover, such a multilayered Brabantine identity might have preceded the rule of the Burgundian dukes. In Brabant, this 'regional' focus was imposed by the Brabantine dukes, but emerged in dialogue with towns and nobility. First, as mentioned, there are the early examples of a regional historiographical tradition with a strong connection to the local elites and towns (such as the thirteenth-century Rymkronyk by Jan van Heelu or Jan van Boendale's Brabantscheyeesten in the fourteenth century). Second, and perhaps more importantly, there is the constitutional tradition of charters issued by the Brabantine dukes. Since the middle of the thirteenth century, the Brabantine dukes issued a testament at the end of their rule in order to smooth the succession..$^{18}$ This resulted in the tradition of institutional charters for the whole Brabantine territory (such as the Charter of Kortenberg of 1312 and the Blijde Inkomsten or the 'Joyous Entry' charters) in the fourteenth century and afterwards. A similar tradition of charters issued for the entire county was, by contrast, absent in Flanders.

For Flanders, examples earlier than the late fourteenth century are rather scarce. Local particularism was relatively high and remained important in the county of Flanders. Various factors impeded a sense of regionalism in the county. First, the region itself is a composite from a feudal point of view, divided between the kingdom of France (Royal Flanders, west of the river Scheldt) and the Holy Roman Empire (Imperial Flanders, east of the river Scheldt). Second, there is the evident language issue. A linguistic 'border' divided the county of Flanders into a francophone south and a Dutch-speaking north. This linguistic border was not only territorial, but also social, as was the case for most principalities in the Netherlands. The Flemish counts, often firmly tied to the French court, were francophone, as was most of the higher nobility. Furthermore, in some of the 'Dutch-speaking' towns, such as Ypres, a patrician elite represented in the benches of aldermen spoke almost exclusively French. ${ }^{19}$ This language issue became problematic only during the early rule of the Burgundian dukes in 1404. This is especially interesting for the present study as the language question was politically attached to a regional identity when French-speaking 'foreigners' occupied 
positions in central institutions ('Flamans flamengans, nés de Flandre'). ${ }^{20}$ In Brabant, stipulations demanding a 'Brabantine origin' for ducal councillors had existed since $1356 .{ }^{21}$

Urban identity was perhaps more straightforward in the county of Flanders due to the exceptional commercial and political position of its towns: roughly one-third of the total population in the county of Flanders consisted of city dwellers. ${ }^{22}$ Although many urban inhabitants never acquired the status of citizen and its associated rights, 'official' city dwellers had a clear judicial status ('burghership'), which provided legal protection and economic privileges. Such a judicial position is absent on the regional level. This is the case for most territories in the Middle Ages, apart from England, where in the thirteenth century denisation (by the king) and naturalisation (by parliament) formed a sort of national judicial statute. ${ }^{23}$ Remarkably, these rights were exclusively granted to foreigners, often merchants. In the Bruges Poortersboeken (lists of new burghers) of the early fifteenth century, a new regulation was written down each time a female citizen acquired burghership: if she should marry someone from outside the county of Flanders ('lands Vlaenderen'), she would lose her citizenship. ${ }^{24}$ As female burghers could transfer their legal status to their husbands in some Flemish cities such as Bruges and Ghent, this new statute would limit citizenship exclusively to inhabitants of the county of Flanders, an indirect proof of a 'regional' identity.

Scholars have mainly focused on the role of the princely dynasty as the unifying factor in the county of Flanders. ${ }^{25}$ Medieval territories were not nations but 'principalities', bound together by the figure of a prince, his blood relatives, and his dynasty. As mentioned above, it was the Flemish dynasty, and, in particular, its representatives through marriages with the

20 Lecuppre-Desjardin, Le royaume inachevé, pp. 322-326.

21 In December 1355, the duchy was inherited by a female ruler, Johanna van Brabant. The concerns on 'foreign ducal advisors' were related to the fear for her husband Wenceslas of Luxemburg appointing his own councillors in the ducal council. Vrancken, Blijde Inkomsten, p. 298.

22 Boone, 'Flemish and Brabantine Identity', p. 180.

23 Lambert and Ormrod, 'Denization'.

24 E.g. Bruges, City Archives, 130 (Poortersboeken), eerste poortersboek (1418-1434), folio 4r ${ }^{\circ}$ (3 februari 1419): 'Kateline Fransoys Donckers dochter geboren van Ghent cochte haer poorterscip upten darden dach van sporkele bi Janne den Ram, in dezer condicien waerd dat zoe hier naer ener man trauwede van buten lands van Vlaendere gheboren dat haer danne haer poorterscip te gheenre bate commen zoude' ('Kateline Fransoys, Doncker's daughter, born in Ghent, bought her burghership through Janne den Ram, on the third day of February, on the condition that if she would marry a man born outside Flanders, she would lose her burghership'). Thanks to Leen Bervoets and Elisa Bonduel for this suggestion.

25 De Ridder, 'Dynastiek en nationaal gevoel'; Stein, 'Nationale identiteiten'. 
royal houses of England and France, that were praised in Petrus Pictor's twelfth-century De Laude Flandriae. In the late medieval period, the figure of the unifying prince remained important. Elodie Lecuppre-Desjardin stated that Burgundian state formation was solely related to the person of the duke, 'a contractual prince', not to a territorial identity. ${ }^{26}$ From the late fourteenth century onwards, regionalism became more and more tied to the Flemish towns. On the one hand, this can indirectly be related to shifts in literary practices. More and more city dwellers and lower lay elites were engaged in writing administrative, literary, and historiographical sources. Regional chronicles are exceptionally interesting in this regard. Often based on early or high medieval dynastic genealogies, regional chronicles shifted their focus from a given princely dynasty to the actual history of the principality and its largest towns. ${ }^{27}$ For the county of Flanders, regional history writing became entangled with urban history writing from the late fourteenth and early fifteenth centuries onwards. ${ }^{28}$ Various city dwellers were engaged in the rewriting of regional chronicles in the fifteenth century.

On the other hand, a new political situation in the late fourteenth and early fifteenth centuries stimulated this trend as well: the institutionalisation of the Four Members of Flanders, a representative council with deputies from the three largest Flemish towns, Ghent, Bruges, and Ypres, and the wealthy rural district around Bruges, the Franc of Bruges ${ }^{29}$ Although these three cities frequently gathered to negotiate with or without the Flemish counts earlier in the fourteenth century, the Four Members gained importance under the rule of the first Burgundian duke, Philip the Bold, and Margaret of Male, heiress to the counts of Flanders. ${ }^{30}$ This was related to the duke's frequent absences from Flanders. Moreover, Philip the Bold stimulated such central organisation of the county. The evolution of the Four Members into an actual representative institution influenced literary culture and historiography. The political position of the towns as representatives of the county needed legitimisation, and called for an ideological programme on who constituted the county of Flanders: the towns or the count.

26 Lecuppre-Desjardin, Le royaume inachevé, pp. 339-344.

27 Van Houts, Local and Regional Chronicles, pp. 20-24.

28 On the issue of urban chronicles in the Low Countries, see Lecuppre-Desjardin, La ville des cérémonies, pp. 68-75; Stein, 'Selbstverständnis oder Identität?'; Van Bruaene, 'Lécriture de la mémoire'; and, recently, the contributions to Caers, Demets and Van Gassen, Urban History Writing.

29 Prevenier, 'Het Brugse Vrije'.

30 Ibid. 
The arrival of the Burgundian dukes stimulated an interest in regional history writing in the commercial towns, in particular, in Bruges. This emergent (Flemish) 'identity' was, however, not dependent on the territory of Flanders as a whole, but rather on the unity between the largest Flemish towns. Regionalism, perhaps as much as particularism, emerged as an answer to the centralising politics of the Burgundian dukes. ${ }^{31}$ Central to this article are two representative case studies: the Imago Flandriae and the origin myth in the Flandria Generosa C, both written by or in the circle of Lubert Hautscilt, abbot of Eeckhout abbey in Bruges and advisor to the Burgundian dukes in the early fifteenth century. Both literary documents are illuminating examples of the 'composite' or 'multilayered' regional identity that emerged under early Burgundian rule in the Flemish cities.

\section{Regional history writing in the county of Flanders: The Flandria Generosa tradition}

The Flandria Generosa chronicles are generally considered the most important regional chronicle group in the county of Flanders. In the late twelfth century, a Benedictine monk from the Saint Bertin abbey in Saint-Omer wrote a short genealogy of the Flemish counts in Latin: the Flandria Generosa A. ${ }^{32}$ Over time, medieval writers translated, rewrote, and expanded the original text into an embellished chronicle. One manuscript of the Ancienne Chronique de Flandre, a rewritten French version of the genealogy, was probably commissioned by Robert of Bethune (d. 1322), or his father Guy of Dampierre (d. 1305). ${ }^{33}$ However, most Flandria Generosa texts and manuscripts cannot directly be related to the comital house. Important for this contribution is another rewritten branch of the complex Flandria Generosa chronicle group. In the aftermath of the Flemish coast uprising in 1323-1328, a Cistercian monk of Clairmarais abbey near Saint-Omer, Bernard of Ypres, revised and continued the original Benedictine genealogy. Later, the so-called Flandria Generosa C or Catalogus et Cronica Principum et Comitum Flandriae was founded upon this Clairmarais continuation. In the course of the fifteenth century, the Latin text was translated into Middle Dutch,

32 Kelders, 'De Flandria Generosa'. This genealogy was based on older genealogies, such as the one incorporated in the Liber Floridus of Lambert of Saint-Omer.

33 Moeglin, 'Une première histoire nationale'. 
and this eventually resulted in the first Middle Dutch prose chronicle of Flanders, the Excellente Cronike van Vlaenderen. ${ }^{34}$

The Flandria Generosa chronicles go through a profound change from the moment of the county's incorporation into the Burgundian realm, when the chronicle was appropriated by the Flemish cities. The Catalogus narrates Flemish history from the mythical origin of the county until the first years of the rule of the Burgundian duke Philip the Good. Due to the lack of original manuscripts, scholars have dated the Catalogus text to quite different periods, from the middle of the fourteenth century in Lille to the court of Duke Philip the Good in $1430 .{ }^{35}$ Recently, I argued that the Catalogus or Flandria Generosa C was written in the Eeckhout abbey of Bruges in the early fifteenth century - probably at the end of the reign of John the Fearless around 1411 - under the patronage of the notable abbot Lubert Hautscilt (abbot from 1393 until his death in 1417). ${ }^{6}$ Hautscilt was a writer himself, an astrologian, but also a cultural and literary patron. ${ }^{37} \mathrm{He}$ founded a religious confraternity in the Eeckhout abbey, the so-called fratres ad succurendum. John Duke of Berry, the elder brother of the Burgundian duke Philip the Bold, was a member, but there were numerous Bruges city dwellers who also belonged to this elite club, including various Bruges burgomasters and the Gruuthuse poet and rederijker ('rhetorician') Jan van Hulst. The composite identity of a figure like Lubert Hautscilt, who had important connections to the Burgundian court and religious societies in Flanders as well as political networks in Bruges, can be retraced in the discourse of the Catalogus.

The Flandria Generosa C is a Flemish chronicle, in its scope and outlook, structured by the succession of the Flemish counts. The author and his intended public shared a particular interest in the history of Bruges. Several additions were made to the original Clairmarais continuation, revealing a Bruges perspective.$^{38}$ For instance, the continuation describes the Revolt of Ghent (1379-1385) and ends with the Bruges factional war and rebellion against Duke John the Fearless at the beginning of the fifteenth century.

34 On the Excellente Cronike van Vlaenderen: Demets, 'The Late Medieval Manuscript Transmission'; Demets, Onvoltooid verleden.

35 Kelders, 'De kronieken van Vlaanderen', pp. 348-349; Lecuppre-Desjardin, La ville des cérémonies, pp. 68-75; Moeglin, 'Les ducs de Bourgogne'.

36 As I argued in my PhD dissertation. See further: Demets, 'De Flandria Generosa C'.

37 On Lubert Hautscilt, see Smeyers, 'Lubert Hautscilt'.

38 Such as the foundation of Damme in the twelfth century, the Bruges Moerlemaye or revolt at the end of the thirteenth century and the introduction of Jan Breydel as captain of the rebels during the Good Friday revolt on 18 May 1302. 
This focus on Bruges can be explained by the network of the author's patron, Lubert Hautscilt. The abbot was not only a prominent figure in the Burgundian context, but he also had a firm political base in his hometown, Bruges. Hautscilt was involved in the yearly renewal (i.e. election) of the benches of aldermen in 1411 and 1413, after the factional conflict in Bruges. Furthermore, Eeckhout abbey served as a meeting place for various urban events.

Besides the obvious Flemish and more implicit urban content, the Catalogus can also be interpreted as a 'Burgundian' chronicle. Although the text only fragmentarily deals with the history of Flanders under Burgundian rule, the appearance of the mythological forestier Liederik of Buc, the son of a Burgundian prince from Dijon, undoubtedly served to display a proBurgundian propaganda message..$^{39}$ More importantly, the inclusion of his legendary progenitor of the Burgundian dukes fits into the ideological programme of Hautscilt in his role as councillor to Philip the Bold and John the Fearless. The abbot worked as a diplomat during the Hundred Years' War, during which he also became an intimate friend of Duke John of Berry. ${ }^{40}$ This combination of Flemish, Burgundian, and urban narrative elements not only relates to early-fifteenth-century politics, but, as I will argue, also to the contemporary need to legitimise a new political and institutional role of the Flemish urban elite in the county of Flanders, and in the wider Burgundian realm. ${ }^{41}$ This discourse is particularly notable in the new Flemish origin myth introduced in the chronicle.

\section{Imagining a territory through its towns: The origin myth of Liederik de Buc and Brugstoc in the Flandria Generosa $\mathrm{C}$ and the Imago Flandriae of Lubert Hautscilt}

At the beginning of the fifteenth century, the county of Flanders had barely recovered from the Revolt of Ghent (1379-1385). The ongoing troubles linked

39 The new origin myth in the Catalogus has been analysed by many scholars: Kelders, 'Laverend tussen de hof der historie en de warande der literatuur'; Lambert, 'Oorsprongsmythen'; Keesman, De eindeloze stad, pp. 487-498.

40 Smeyers, 'Lubert Hautscilt'.

41 The urban view is central in this contribution. In the article by Bram Caers and Robert Stein in this volume, we see how noble families had their own ancestral histories written into the dominant narrative of the ducal dynasty in the duchy of Brabant. Similar conclusions on noble history writing can be made for the county of Flanders. See Buylaert, 'Memory'; Buylaert et al., 'Politics'. 
to the Hundred Years' War culminated during the reign of John the Fearless (1404-1419), particularly after the murder of Louis of Orléans in 1407. In Bruges, a civil war emerged, initiated by the Burgundian duke, which lasted from 1407 until around $1411 .{ }^{42}$ Around this turbulent political period, the Catalogus was written at Eeckhout abbey. The first case I want to address in this contribution is the new origin myth written in the Flandria Generosa $\mathrm{C}$ or Catalogus. This myth introduced a descendant of a Burgundian line of princes, Liederic de Buc, as the first ruler of the county of Flanders. Of course, this suggestion that the Flemish dynasty was originally 'Burgundian' primarily served to legitimise Burgundian rule in the county. Several details in the new origin myth point to the conflict of the Hundred Years' War, such as the banishment of Liederik's father and mother from France after a dispute with the eldest son of the French king and Liederik's short affair with an English princess. However, more specifically, the origin myth has an underlying hope for a peace treaty: Liederik eventually marries a French princess and reconciles with the French king. Of course, it is not exceptional for origin myths to refer to contemporary political problems. ${ }^{43}$ It would appear that the political situation at the beginning of the fifteenth century called for a new origin of the county of Flanders referring to contemporary Burgundian politics, as did the position of the major towns in this new political reality.

Scholars have overlooked the obviously 'urban' and, more specifically, Bruges-related elements in the new origin myth. For instance, Bruges is described as a flourishing harbour with established commercial connections to England. When Liederik was forced to flee England after his affair with the princess, the Catalogus writes how he sailed from Dover to Bruges ('Brugstoc'), where he stayed with a friendly local innkeeper or broker. ${ }^{44}$ The innkeeper recognised Liederik as the lost prince and informed him about his mother, still locked away in the castle of Lillebuc by the giant Finard. The innkeeper accompanied Liederik to Lille where Liederik slayed the giant. Afterwards, Liederik was asked by the people of Flanders to become their ruler. The Catalogus clearly and rather boldly describes how the city of Bruges was an attractive and wealthy harbour prior to the foundation of the comital house. The Catalogus also mentions how the new Flemish ruler, Liederik de Buc, founded a castrum on the Burg in Bruges and a small chapel which would eventually become Saint Donatian's Church. These 
details seem random at first sight, but they have a clear territorial political implication from the perspective of political 'areas' within the town: the Burg in Bruges was the oldest part of the town associated with comital power (as represented by the castrum and later the town hall), whereas the market square held the burghers' political symbols such as the Belfry. The harbour can be seen as a symbol referring to these commercial urban networks in Bruges. Moreover, according to the myth, these networks existed well before the princely castrum founded by Liederik de Buc. ${ }^{45}$ The exact age or foundation of Bruges was probably left deliberately vague, suggesting that the cities in the county of Flanders were older than history itself. In short, the new origin myth not only highlighted the Burgundian descent of the comital house, but also argued how the cities in the county of Flanders were much older than the first Burgundian forestier of Flanders. ${ }^{46}$

This could be one of the reasons why the myth of Liederik de Buc was never adopted by the Burgundian court historiographers and remained in the collective memory of urban society, in particular, the inhabitants of Bruges ${ }^{47}$ This seems strange at first, with regard to the position of Lubert Hautscilt as a ducal advisor. Still, the seemingly innocent role of the Bruges innkeeper could refer to an urban intended audience of the Flandria Generosa $\mathrm{C}$ and the wider urban networks of Lubert Hautscilt. In this regard, it is interesting to look at the Hautscilt family's position in Bruges, as they were themselves innkeepers and brokers with Hanseatic roots, and had been active in Bruges from the beginning of the fourteenth century. ${ }^{48}$ The link with the Bruges brokers and innkeepers in the origin myth also leads us to a new cultural and political organisation that emerged in the $1390 \mathrm{~s}$ in Bruges, an organisation led by a forestier: the urban jousting society of the White Bear. ${ }^{49}$ Members of this elite urban society were mainly brokers and wealthy craftsmen. Furthermore, there is a clear link with Eeckhout abbey. Descriptions in the early-fifteenth-century cartulary of the abbey

45 The castrum is the oldest part of Bruges: Verhulst, The Rise of Cities, pp. 88-9o.

46 For example, the Catalogus mentions how Ghent had been founded by Julius Caesar. The Roman origin of Ghent was based on the Saint Bavo legend: Keesman, De eindeloze stad, pp. 498-499.

47 The origin myth of Liederik de Buc was given a prominent place in a tableau vivant during the Joyous Entry of Charles the Bold in 1515. Mareel, 'Jan de Scheereres'.

48 Demets, Onvoltooid verleden, pp. 78-85.

49 Brown, 'Urban Jousts'. The White Bear of Bruges was probably also a literary society as many early-fifteenth-century Bruges literary texts have been attributed to this milieu, including a number in the Gruuthuse manuscript, in particular the poem the 'Seven Gates of Bruges'. Dumolyn, 'Une idéologie urbaine "bricolée”. 
of Eeckhout show how the jousters organised meetings at the abbey.$^{50}$ For their annual tournament each May, they assembled at the grounds of the abbey before they marched and rode to the Great Market. It follows that this new origin myth could have been used as a theme for one of the society's jousts or gatherings, perhaps in the presence of the Burgundian duke. This performative aspect is important with regard to the 'composite' urban, Flemish, and Burgundian identity emerging among these urban patrician elites in the early fifteenth century. Many of the jousters of the White Bear were members of important political families in Bruges, and represented the city in the meetings of the Four Members of Flanders..$^{1}$ Perhaps, more than legitimising the Burgundian dynasty, the new origin myth links the success of the comital and 'Burgundian' dynasty to these urban elites.

Arguably, the Catalogus can be related to the networks of Lubert Hautscilt only indirectly. Nevertheless, the Eeckhout abbot was the author of a contemporary literary text, the Imago Flandriae. The Imago Flandriae is a Latin poem and image containing a prophecy on the future of Flanders. It was written by Lubert Hautscilt around 1400, and was transmitted widely and applied to many crises in Flanders such as the Eighty Years' War (1568-1648). The original prophecy was lost, but several sixteenth- and seventeenth-century printed copies have been preserved. Prophecies were written intentionally vaguely so as to be applicable to various future political events. ${ }^{5}$ The original prophecy, however, was obviously composed in the context of the Hundred Years' War between France and England, as it warns the major cities of Flanders, or 'GYBID', that is, Ghent, Ypres, Bruges, Lille ('Insula'), and Douai, of the political and economic consequences of the war. The discourse of the prophecy in the context of the Hundred Years' War is equally omnipresent in the Flandria Generosa C, and relevant for an urban context as the largest Flemish towns depended on the English trade. Moreover, the prophecy shows striking similarities to the Properheden van den steden van Vlaendren (The properties of the towns of Flanders) written around 1380. An anonymous author, probably linked to the jousting society of the White Bear in Bruges as well, described Flanders ('dus hebben wij Vlaendren int ronde') by listing $5^{8}$ Flemish towns along with a local characteristic, an eating habit, their political or social standing, or cultural markers. ${ }^{53}$ Not coincidentally, the Properheden starts with the Four Members of Flanders 


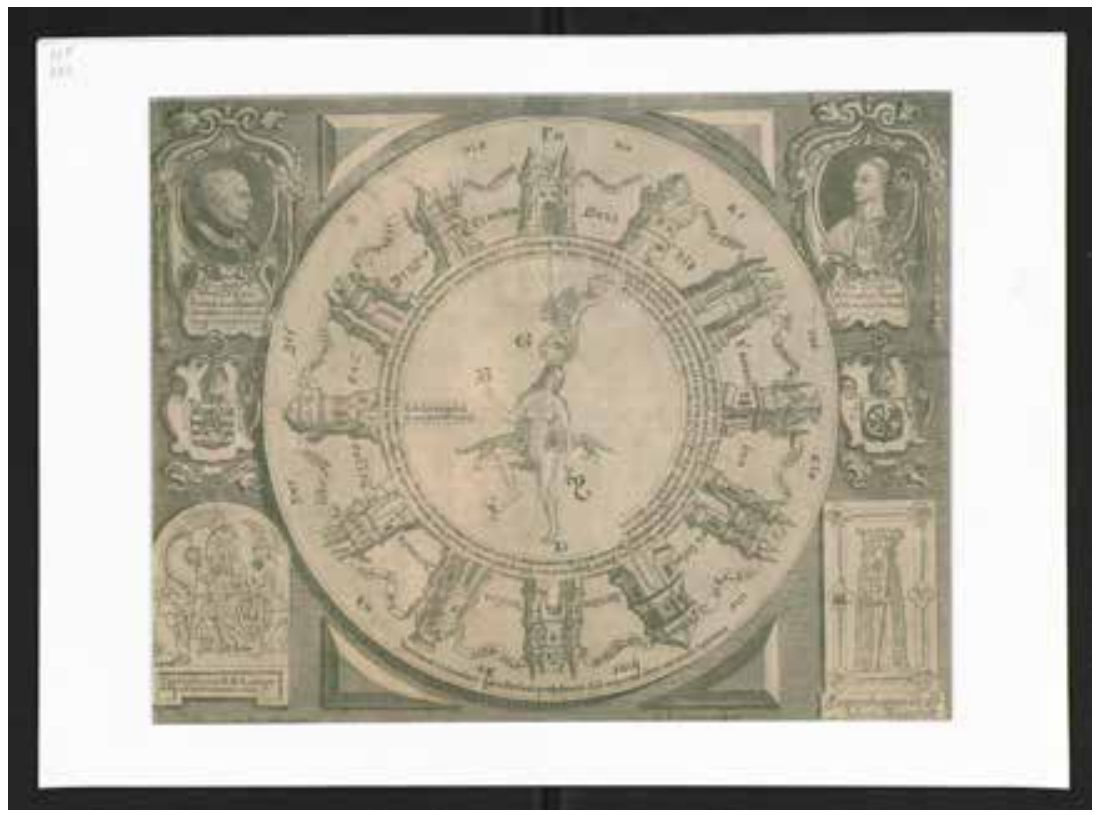

11.1. Imago Flandriae of Lubert Hautscilt by Jacob Van Oost II and Pieter De Brune (Brugge: Lucas Vanden Kerckhove, 1671). ๑ Public Library Bruges, H.F. 226.

'Heeren van Ghendt. Poerters van Brugghe. Kindre van Ypere. Darinc berders van den Vrien' ('Lords of Ghent. Burghers of Bruges. Children of Ypres. Peat fires of the Franc'). ${ }^{4}$ This hierarchy between the towns can also be detected in the Imago Flandriae.

The prophecy itself belongs to a larger pictorial and textual entity: a clarifying poem was written in a band around an allegorical representation of the county of Flanders. ${ }^{55}$ The naked woman in the middle of the image symbolises Flanders, nursing two wolves representing England and France. In this way, the Imago Flandriae bears a resemblance to the allegory of city maidens, symbolising the purity of the town and its need for protection, a recurrent political image in the late medieval and early modern Low Countries..$^{6}$ The letters surrounding the woman's body refer to the five largest Flemish towns, and were written each next to a different body part, representing the body politic of Flanders. ${ }^{57}$ Ghent is her head, Bruges her right hand, Ypres her left hand, and Douai and Lille her feet. These are not 
the only territorial aspects of the image: the woman is also enclosed by the city gates of several Flemish towns. ${ }^{8}$ The Flemish towns are thus central in this allegorical representation of Flanders: they are the body, the head, and the limbs of the county, but equally serve as a protective hortus conclusus ('enclosed garden'). The placement of the letters referring to the five largest cities next to the image of Flanders is not random and stands in direct relation to the prophecy predicting the loss of Douai and Lille: 'Gyb fiet ex GYBID, cum deca decas ibit' ('GYB will come forth out of GYBID, when ten decades have passed'). ${ }^{59}$ Although the pictorial representation implies a hierarchy (Ghent as the head, the leading town of the Four Members), the prophecy-poem clearly describes them as a unity: GYBID dilecta ('beloved GYBID'). Strikingly, Flanders is not once mentioned in the poem, nor is the comital house or the duke. The county of Flanders is instead represented by the unity of its most important towns and protected by its gates and walls.

\section{Conclusion}

The question of whether and how urban elites of the county of Flanders identified themselves with the Flemish territory cannot be answered straightforwardly. Nevertheless, the interest in a Flemish chronicle in urban milieux increased from the moment the county was incorporated into a larger territorial entity, the Burgundian composite state. In this contribution, I discussed two literary products from the early fifteenth century: the origin myth of Liederik de Buc in a newly written regional chronicle, the Catalogus et Cronica Principum et Comitum Flandriae (or Flandria Generosa C), and a prophecy on the future of Flanders, the Imago Flandriae. These texts were produced in an elite milieu in Bruges around the figure of the abbot of Eeckhout, Lubert Hautscilt, who was connected to urban society in Bruges (through the jousting society of the White Bear) as well as to the Burgundian court. His literary texts show how the Burgundian dynasty was integrated into Flemish history, but even more that 'Flanders' was viewed as an entity constituted by its towns, in particular the largest cities of Ghent, Bruges, and Ypres. The cities were the political body of the county, represented by a naked woman in the Imago Flandriae prophecy and protected by urban features (walls and gates). The head and limbs of Flanders were composed

$5^{8}$ The towns differ according to the edition, so probably they were adapted over time. Hautscilt made a clear statement by depicting the gates wide open.

59 Hautscilt, Imago Flandriae, p. 85. 
of the five largest towns: Ghent, Bruges, Ypres, Lille, and Douai. A regional identity emerged as a call for unity between the Flemish cities. Of course, the question remains whether such a constructed 'regional identity', a political ideology, ever truly surpassed the particularising tendencies of the towns, and even the individual elite urban factions within the Flemish cities.

Around 1111, the poem of Petrus Pictor illustrated how the Flemish dynasty gave shape to expressions of the county's regional identity. In the early fifteenth century, the towns gradually claimed this representational position: by integrating their history into the origin myth of the comital house. The role of the three largest Flemish cities, introduced in the origin myth and the text of the Catalogus or Flandria Generosa $C$, was elaborated in the rewriting of the text during the fifteenth century. In the Excellente Cronike van Vlaenderen, the Middle Dutch translation and continuation of the Catalogus, the "Three Cities' appear as an institution, a prominent historical actor, as a protector of the county, and projected back through time onto the earliest history of the county.$^{60}$ Similar to the representation of the Flemish towns in the Imago Flandriae, they function as a sort of defender of the balanced relationship between the prince and his subjects, appearing as a deus ex machina at times of conflict, restoring order by calling for the rightful count. Late medieval Flemish readers would link the appearance of the Three Cities with the late medieval institution, the Four Members of Flanders. Like its Middle Dutch translations and continuations, the Catalogus was not commissioned by or explicitly dedicated to the Burgundian dukes. Nevertheless, its intended audience was clearly a pro-Burgundian, Flemish and urban elite assembled in the representative institution of the Four Members of Flanders. In this way, the Catalogus as well as the Imago Flandriae legitimised the role of the towns in regional politics. The Four Members saw themselves as the true guardians of the Flemish heritage, willing to protect it against 'foreigners'. Or, as the new origin myth in the Catalogus implicitly states: Bruges was already a wealthy harbour before the arrival of the prince of Dijon.

\section{Bibliography}

\section{Primary sources}

Bruges, City Archives, 130 (Poortersboeken), Eerste Poortersboek (1418-1434). Bruges, Public Library, H.F. 226. 
Catalogus et Cronica Principum et Comitum Flandrie, ed. by J.J. de Smet, in Recueil des chroniques de Flandre - Corpus chronicorum Flandriae (Brussel: Hayez, 1837), pp. 19-257.

Hautscilt, Lubert, Imago Flandriae, ed. and trans. by Maurits Smeyers, in 'Lubert Hautscilt, abt van de Brugse Eeckhoutabdij (1393-1417). Over handschriften, planeten en de toekomst van Vlaanderen', Academiae Analecta. Mededelingen van de Koninklijke Academie voor Wetenschappen, Letteren en Schone Kunsten van België 55 (1995), 41-104.

Petrus Pictor, De Laude Flandriae, ed. and trans. by Lieven Van Acker, 'Petrus Pictor en zijn “De Laude Flandriae”, De Franse Nederlanden 8 (1983), 129-145.

De Properheden van den Steden van Vlaendren, ed. by Antoon Viaene, in 'De Properheden van den Steden van Vlaendren 1380-1400', Biekorf 77 (1977), 129-133.

\section{Secondary sources}

Anthias, Floya, 'Identity and Belonging: Conceptualisations and Political Framings', KLA Working Paper Series, Working Paper, no. 8 (2013), https://kompetenzla. uni-koeln.de/sites/fileadmin2/WP_Anthias.pdf.

Anthias, Floya, 'Where Do I Belong? Narrating Collective Identity and Translocational Positionality', Ethnicities 2 (2004), 491-514.

Blockmans, Wim, 'Regionale Identität und staatliche Integration in den Niederlanden 13.-16. Jahrhundert', in Nationale, ethnische Minderheiten und regionale Identitäten in Mittelalter und Neuzeit, ed. by Antoni Czacharowski (Torun, 1994), pp. 137-149.

Boone, Marc, 'Flemish and Brabantine Identity in Late Medieval/Early Modern Europe: Cities and Princes in the Contest for Mastering Regional Identities', Spiel 21 (2002), 178-186.

Brown, Andrew, 'Bruges and the Burgundian 'Theatre-State': Charles the Bold and Our Lady of the Snow', History: The Journal of the Historical Association 84 (1999), 573-589.

Brown, Andrew, Civic Ceremony and Religion in Medieval Bruges (ca. 1300-1520) (New York: Cambridge University Press, 2011).

Brown, Andrew, 'Urban Jousts in the Later Middle Ages: The White Bear of Bruges', Belgisch Tijdschrift voor Filologie en Geschiedenis 78 (2000), 315-330.

Buylaert, Frederik, 'Memory, Social Mobility and Historiography. Shaping Noble Identity in the Bruges Chronicle of Nicholas Despars (+1597)', Belgisch Tijdschrift voor Filologie en Geschiedenis 87 (2010), 377-408.

Buylaert, Frederik, Jelle Haemers, Tjamke Snijders and Stijn Villerius, 'Politics, Social Memory and Historiography in Sixteenth-Century Flanders: Towards a 
Research Agenda', Publications du Centre Européen d'Etudes Bourguignonnes $5^{2}$ (2012), 195-215.

Caers, Bram, Lisa Demets and Tineke Van Gassen, eds, Urban History Writing in Northwest Europe (15 ${ }^{\text {th }}-16^{\text {th }}$ Centuries) (Turnhout: Brepols, 2019).

Demets, Lisa, 'De Flandria Generosa C. Een Kroniek van Vlaanderen uit de Brugse Eeckhoutabdij aan het begin van de vijftiende eeuw', Handelingen van het Genootschap voor Geschiedenis 157 (2020), 39-71.

Demets, Lisa, 'In omni terra potestatis mei: discours, macht en legitieme autoriteit in de oorkonden van de hertogen van Brabant (1106-1248)', Revue belge de philologie et d'histoire 95 (2017), 193-218.

Demets, Lisa, 'The Late Medieval Manuscript Transmission of the "Excellente Cronike Van Vlaenderen" in Urban Flanders', The Medieval Low Countries 3 (2016), 123-173.

Demets, Lisa, Onvoltooid verleden. De handschriften van de Excellente Cronike van Vlaenderen in de laatmiddeleeuwse Vlaamse steden (Hilversum: Verloren, 2020). Demets, Lisa, and Jan Dumolyn, 'La ville comme Sainte Vierge. Un aspect de l'idéologie urbaine en Flandre médiévale (fin du XIV siècle-début du XVI ${ }^{\mathrm{e}}$ siècle)', Cahiers électroniques d'histoire textuelle du Laboratoire de Médiévistique Occidentale de Paris 9 (2016), 24-52.

Demets, Lisa, Jan Dumolyn and Els De Paermentier, 'Political Ideology and the Rewriting of History in Fifteenth-Century Flanders', BMGN: The Low Countries Historical Review 134 (2019), 73-95.

De Ridder, Paul, 'Dynastiek en nationaal gevoel in Brabant onder de regering van Hertog Jan I (1267-1294)', Handelingen van de Koninklijke Zuidnederlandse Maatschappij voor Taal- en Letterkunde 33 (1979), 73-99.

Dumolyn, Jan, De Brugse Opstand van 1436-1438 (Heule: UGA, 1997).

Dumolyn, Jan, 'Justice, Equity and the Common Good: The State Ideology of the Councillors of the Burgundian Dukes', in The Ideology of Burgundy: The Promotion of National Consciousness, 1364-1565, ed. by Jonathan Boulton and Jan Veenstra (Leiden: Brill, 2006), pp. 1-20.

Dumolyn, Jan, Staatsvorming en vorstelijke ambtenaren in het graafschap Vlaanderen (1419-1477) (Leuven: Garant, 2003).

Dumolyn, Jan, 'Une idéologie urbaine "bricolée” en Flandre médiévale: "les sept portes de Bruges” dans le manuscrit Gruuthuse (début du XVe siècle)', Belgisch Tijdschrift voor Filologie en Geschiedenis 88 (2010), 1039-1084.

Dumolyn, Jan, 'Urban Ideologies in Later Medieval Flanders: Towards an Analytical Framework', in The Languages of Political Society: Western Europe, $14^{\text {th }}-17^{\text {th }}$ Century, ed. by Andrea Gamberini, Jean-Philippe Genet and Andrea Zorzi (Rome: Viella, 2011), pp. 69-96. 
Dumolyn, Jan, and Jelle Haemers, “A Blabbermouth Can Barely Control His Tongue”: Political Poems, Songs, and Prophecies in the Low Countries (Fifteenth-Sixteenth Centuries)', in Spoken Word and Social Practice: Orality in Europe (1400-170o): Medieval and Renaissance Authors and Texts, ed. by Thomas Cohen and Lesley Twomey (Leiden: Brill, 2015), pp. 280-299.

Elden, Stuart, 'Land, Terrain, Territory', Progress in Human Geography 34, no. 6 (2010), 799-817.

Fris, Victor, 'Het Brugsche Calfvel van 1407-1411', Bulletin de l'Académie d'Archéologie de Belgique (1910), 183-274.

Guenée, Bernard, Histoire et culture historique dans l'Occident médiéval (Paris: Aubier Montaigne, 1980).

Haemers, Jelle, For the Common Good: State Power and Urban Revolts in the Reign of Mary of Burgundy (1477-1482) (Turnhout: Brepols, 2009).

Huizinga, Johan, and Anton Van der Lem. Herfsttij der Middeleeuwen: studie over levens- en gedachtenvormen der veertiende en vijftiende eeuw in Frankrijk en de Nederlanden (Leiden: Leiden University Press, 2018).

Keesman, Wilma, De eindeloze stad: Troje en Trojaanse oorsprongsmythen in de (laat)middeleeuwse en vroegmoderne Nederlanden (Hilversum: Verloren, 2017). Kelders, Ann, 'De Flandria Generosa', in The Encyclopedia of the Medieval Chronicle, ed. by Graeme Dunphy (Leiden: Brill, 2010), pp. 621-622.

Kelders, Ann, 'De kronieken van Vlaanderen: aspecten van de laat-middeleeuwse historiografie in de Flandria Generosa C', MA thesis, Rijksuniversiteit Gent, 1989-1990.

Kelders, Ann, 'Laverend tussen de hof der historie en de warande der literatuur. Kroniekschrijving in het graafschap Vlaanderen', in Medioneerlandistiek. Een inleiding tot de Middelnederlandse letterkunde, ed. by Ria Jansen-Sieben, Jozef Janssens and Frank Willaert (Hilversum: Verloren, 200o), pp. 167-177.

Lambert, Bart, and Mark Ormrod, 'Denization: Friendly Foreigners: International Warfare, Resident Aliens and the Early History of Denization in England, c. 1250-c. 1400', The English Historical Review 130 (2015), 1-24.

Lambert, Véronique, 'Oorsprongsmythen en nationale identiteit. De forestiers van Vlaanderen', De Leiegouw 48 (2006), 189-246; 49 (2007), 97-121 and 163-181.

Lecuppre-Desjardin, Elodie, La ville des cérémonies. Essai sur la communication politique dans les anciens Pays-Bas Bourguignons (Turnhout: Brepols, 2004).

Lecuppre-Desjardin, Elodie, Le royaume inachevé des ducs de Bourgogne (XIV ${ }^{e}-X V^{e}$ siècles) (Paris: Belin, 2016).

Mareel, Samuel, 'Jan de Scheereres triumphe ghedaen te Brugghe ter Intreye van Caerle. Teksteditie met inleiding en aantekeningen', Jaarboek de Fonteine 55 (2005), 79-143. 
Moeglin, Jean-Marie, 'Les ducs de Bourgogne et l'historiographie flamande', in Les historiographes en Europe de la fin du Moyen Âge à la révolution, ed. by Chantal Grell (Paris: Presses de l'université Paris-Sorbonne, 2006), pp. 21-36.

Moeglin, Jean-Marie, 'Une première histoire nationale flamande. L'Ancienne Chronique de Flandre (XII ${ }^{\mathrm{e}}$-XIII ${ }^{\mathrm{e}}$ siècles)', in Liber largitorius, études d'histoire médiévale offertes à Pierre Toubert par ses élèves, ed. by Dominique Barthélemy and Jean-Marie Martin (Genève: Librairie Droz, 2003), pp. 455-476.

Nederman, Cary Joseph, and Kate Langdon Forhan, Medieval Political Theory: A Reader: The Quest for the Body Politic, 1100-140o (Londen: Routledge, 1993).

Pajic, Milan, 'Flemish Rebels in Exile: Their Perception in $14^{\text {th }}$ Century London and the Creation of New Identities', in Peuples conquérants, peuples conquis. Perception identitaires au Moyen-Âge en Europe (IX $X^{e}-X V^{e}$ siècle), ed. by Tatjana Silec-Plessis and Alessandra Stazzone (Paris: AMAES, 2015), pp. 187-206.

Prevenier, Walter, 'Het Brugse Vrije als Vierde lid van Vlaanderen', in Handelingen van het XXII ${ }^{e}$ Vlaams Filologencongres (Leuven, 1957), pp. 307-311.

Prevenier, Walter, and Thérèse de Hemptinne, 'La Flandre au Moyen Âge. Un pays de trilinguisme administratif', in La langue des actes, ed. by Olivier Guyotjeannin (Paris: éditions en ligne de l'Ecole des Chartes, 2005), pp. 1-16.

Ramakers, Bart, 'Van maagden en poorten. Stadsmetaforen in historische toneelstukken', in Nederland stedenland: continuïteit en vernieuwing, ed. by Ed Taverne, Jaap Evert Abrahamse and Judith Van den Bos (Rotterdam: naio1o, 2012), pp. 178-192.

Small, Graeme, 'Les Chroniques de Hainaut et les projets d'historiographie régionale en langue française à la cour de Bourgogne', in Les chroniques de Hainaut ou les ambitions d'un prince bourguignon, ed. by Pierre Cockshaw and Christiane Van den Bergen-Pantens (Turnhout: Brepols, 2000), pp. 17-22.

Small, Graeme, 'Local Elites and "National” Mythologies in the Burgundian Dominions in the Fifteenth Century', in Building the Past. Konstruktion der eigenen Vergangenheit, ed. by Rudolf Suntrup and Jan Veenstra (Frankfurt: Peter Lang, 2006), pp. 229-245.

Smeyers, Maurits, 'Lubert Hautscilt, abt van de Brugse Eeckhoutabdij (1393-1417). Over handschriften, planeten en de toekomst van Vlaanderen', Academiae Analecta. Mededelingen van de Koninklijke Academie voor Wetenschappen, Letteren en Schone Kunsten van België 55 (1995), 41-104.

Stein, Robert, 'Introduction', in Networks, Regions and Nations: Shaping Identities in the Low Countries, 1300-1650, ed. by Robert Stein and Judith Pollmann (Leiden: Brill, 2009), pp. 1-18.

Stein, Robert, 'Nationale identiteiten in de Late Middeleeuwen. Een verkenning', Tijdschrift voor Sociale Geschiedenis 28 (2002), 222-246. 
Stein, Robert, Politiek en historiografie. Het ontstaansmilieu van Brabantse kronieken in de eerste helft van de vijftiende eeuw (Leuven: Peeters, 1994).

Stein, Robert, 'Selbstverständnis oder Identität? Städtische Geschichtsschreibung als Quelle für die Identitätsforschung', in Memoria, communitas, civitas. Mémoire et conscience urbaines en occident à la fin du Moyen Âge, ed. by Hanno Brand, Pierre Monnet and Martial Staub (Ostfildern: Jan Thorbecke Verlag, 2003), pp. 181-202.

Van Acker, Lieven, 'Petrus Pictor en zijn “De Laude Flandriae”', De Franse Nederlanden 8 (1983), 129-145.

Van Bruaene, Anne-Laure, 'The Habsburg Theatre State: Court, City and the Performance of Identity in the Early Modern Southern Low Countries', in Networks, Regions and Nations: Shaping Identities in the Low Countries 1300-1650, ed. by Robert Stein and Judith Pollmann (Leiden: Brill, 2010), pp. 131-149.

Van Bruaene, Anne-Laure, 'L'écriture de la mémoire urbaine en Flandre et en Brabant (XIV ${ }^{\mathrm{e}}-\mathrm{XVI}^{\mathrm{e}}$ siècle)', in Villes de Flandre et d'Italie (XIII ${ }^{e}-X I^{e}$ siècles): les enseignements d'une comparaison, ed. by Elisabeth Crouzet-Pavan and Elodie Lecuppre-Desjardin (Turnhout: Brepols, 2008), pp. 149-164.

Van Houts, Elisabeth, Local and Regional Chronicles (Turnhout: Brepols, 1995).

Verbruggen, Jan-Frans, 'Het nationaal gevoel in het graafschap Vlaanderen voor en na 1302', Genootschap voor Geschied-en Oudheidkunde te Vilvoorde 8 (2002), 3-12.

Verhulst, Adriaan, The Rise of Cities in North-western Europe (Cambridge: Cambridge University Press, 1999).

Vrancken, Valerie, De Blijde Inkomsten van de Brabantse hertogen. Macht, opstand en privileges in de vijftiende eeuw (Brussels: Academic and Scientific Publishers, 2018).

Werner, Karl Ferdinand, 'Les nations et le sentiment national dans l'Europe médiévale', Revue Historique 244 (1970), 285-304.

\section{About the author}

Lisa Demets is a postdoctoral researcher at Utrecht University and Ghent University. Her main research interests are multilingualism, manuscripts, gender history, chronicle writing and the political and cultural history of the medieval Low Countries. 